\title{
MANAJEMEN APARATUR SIPIL NEGARA DALAM MEWUJUDKAN TATA KELOLA PEMERINTAHAN YANG BAIK
}

\author{
Agung Kurniawan \\ Mahasiswa Magister Ilmu Pemerintahan, Program Pasca Sarjana \\ Universitas Muhammadiyah Yogyakarta \\ mazakur@gmail.com \\ Suswanta \\ Dosen Magister Ilmu Pemerintahan, Program Pasca Sarjana \\ Universitas Muhammadiyah Yogyakarta \\ soesumy@yahoo.com
}

\begin{abstract}
Abstrak
Kebijakan moratorium yang diberlakukan pemerintah menyebabkan ketidakseimbangan antara jumlah formasi jabatan dengan jumlah personil yang ada. Manajemen terhadap struktur organisasi dan sumber daya manusia perlu untuk dilakukan agar administrasi pemerintahan dapat berjalan secara efektif. Sumber Daya Manusia merupakan unsur penting di dalam organisasi pemerintahan sehingga harus dipastikan bahwa telah dilakukan proses pengelolaan SDM secara tepat sehingga akan meningkatkan kinerja secara optimal. Penelitian ini bertujuan untuk mengetahui upaya upaya yang telah dilakukan oleh Pemerintah Kabupaten Kulon Progo dalam melakukan manajemen sumberdaya manusia khususnya dalam hal penataan dan pengembangan kompetensi Aparatur Sipil Negara (ASN) dalam kurun waktu pelaksanaan kebijakan moratorium ASN. Metode penelitian yang digunakan adalah deskriptif kualitatif dengan teknik pengumpulan data melalui wawancara, dokumentasi dan observasi. Hasil penelitian menunjukkan bahwa Pemerintah Daerah Kabupaten Kulon Progo telah berusaha untuk melakukan manajemen sumber daya ASN melalui proses pengembangan database kepegawaian, penataan dan redistribusi pegawai, penyusunan standar kompetensi dan pengembangan diklat berbasis kompetensi. Upaya tersebut memberikan hasil yang cukup baik yang dilihat dari capaian kinerja Pemerintah Kabupaten Kulon Progo.
\end{abstract}

Kata Kunci: Manajemen ASN, Reformasi Birokrasi, Moratorium

\section{Pendahuluan}

Penyelenggaraan pemerintahan di Indonesia telah mengalami perkembangan pesat dari sentralistik menuju kepada desentralisasi. (DJAJAKUSUMAH, 2016) Perubahan tersebut juga diikuti dengan perubahan paradigma pemerintahan dari "Rule Government" menuju "Good Governance". Hal tersebut bertujuan agar terjadi percepatan dalam peningkatan kualitas pelayanan masyarakat, serta perbaikan terhadap fungsi birokrasi yang dianggap masih memiliki banyak kekurangan karena banyak disalahgunakan. (Idris, 2017) Selain itu birokrasi di Indonesia merupakan birokrasi yang miskin inovasi karena tidak memiliki iklim yang mendorong adanya inovasi serta birokrat yang tidak mendapatkan permasalahan berat jika tidak bekerja secara produktif. (Agus, 
2019) Akibat dari adanya hal tersebut maka birokrasi menjadi kurang efisien dan terjadi praktek penyimpangan seperti korupsi dan penyalahgunaan kewenangan.

Birokrasi merupakan bagian dari sistem sosial yang memiliki dinamika sesuai dengan lingkungannya. Perkembangan demokrasi yang membawa konsep kebebasan, partisipasi, kesetaraan dan rasionalitas serta semakin kritisnya masyarakat menuntut pemerintah untuk memiliki sistem birokrasi yang memiliki berbagai macam inovasi dan menyediakan SDM yang jujur dan terbuka. (Agus, 2019) Namun untuk mencapai tahapan tersebut diperlukan upaya yang sungguh sungguh dari berbagai pihak sebab masih terdapat permasalahan dari internal birokrasi diantaranya pelanggaran disiplin, penyalahgunaan wewenang, rendahnya kinerja sumber daya aparatur, sistem organisasi dan manajemen pemerintahan yang belum memadai, rendahnya efisiensi dan efektivitas kerja, rendahnya kualitas pelayanan umum, rendahnya kesejahteraan PNS serta berbagai peraturan perundang undangan yang sudah tidak sesuai dengan perkembangan zaman (Sunarno, 2020).

Reformasi birokrasi merupakan salah satu upaya pemerintah untuk menyelesaikan permasalahan tersebut. Pelaksanaan reformasi birokrasi memerlukan komitmen yang sungguh dari berbagai pihak yang terlibat di dalam pemerintahan. Terdapat delapan area perubahan yang harus dilakukan perbaikan oleh semua kementerian dan lembaga baik pusat maupun daerah meliputi: manajemen perubahan, penataan peraturan perundang undangan, penataan dan penguatan organisasi, penataan tatalaksana, penataan sistem manajemen SDM, penguatan akuntabilitas, penguatan pengawasan dan peningkatan pelayanan publik. Keberhasilan perbaikan dalam delapan area tersebut diharapkan mampu memenuhi pencapaian sasaran pemerintah sebagaimana tercantum di dalam Peraturan Presiden Nomor 81 Tahun 2010 tentang Grand Desain Reformasi Birokrasi 2010 - 2024 yaitu: Pemerintahan yang bersih, akuntabel dan berkinerja tinggi, Pemerintahan yang efektif dan efisien serta pelayanan publik yang baik dan berkualitas. Untuk dapat mencapai sasaran tersebut perlu dilakukan perbaikan manajemen organisasi dan SDM sehingga tercapai keseimbangan antara unit/stuktur organisasi. 


\section{Grafik 1}

Perkembangan Jumlah PNS di Indonesia

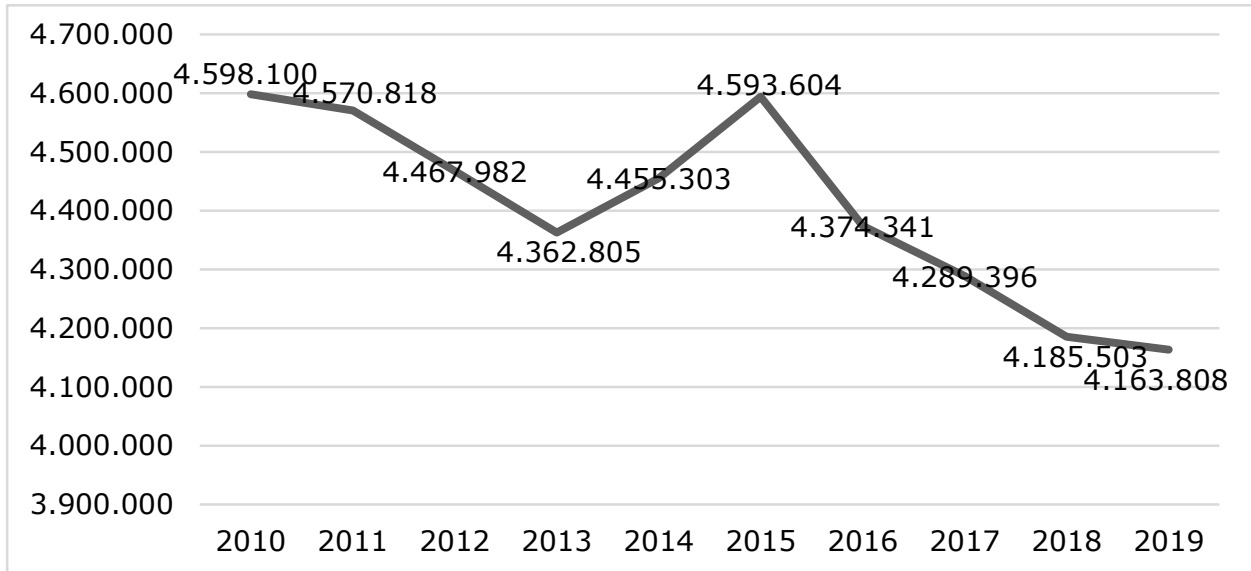

Sumber : Badan Kepegawaian Negara, 2020

Per 31 Desember 2019 jumlah total ASN di Indonesia baik yang berada di instansi pusat maupun instansi daerah adalah adalah 4.189 .121 orang. Jumlah tersebut cenderung mengalami penurunan dari tahun ke tahun sebagaimana dapat dilihat dari grafik di atas dikarenakan adanya ASN yang memasuki masa purna tugas dan penerapan kebijakan moratorium yang dilakukan oleh pemerintah.

\section{Tabel 1}

Jumlah ASN Berdasarkan Usia

\begin{tabular}{|c|r|r|r|}
\hline Usia & Instansi Daerah & \multicolumn{1}{c|}{ Instansi Pusat } & \multicolumn{1}{l|}{ Total } \\
\hline $18-20$ & 686 & 1 & 687 \\
\hline $21-25$ & 40.182 & 21.222 & 61.404 \\
\hline $26-30$ & 70.228 & 99.837 & 170.065 \\
\hline $31-35$ & 103.836 & 297.978 & 401.814 \\
\hline $36-40$ & 139.270 & 514.912 & 654.182 \\
\hline $41-45$ & 140.990 & 488.339 & 629.329 \\
\hline $46-50$ & 154.623 & 493.570 & 648.193 \\
\hline $51-55$ & 172.282 & 701.220 & 873.502 \\
\hline $56-60$ & 113.343 & 611.289 & 724.632 \\
\hline Jumlah & 935.440 & 3.228 .368 & 4.163 .808 \\
\hline
\end{tabular}

Sumber : Badan Kepegawaian Negara, 2020

Berdasarkan tabel di atas, ASN terbanyak berada di kelompok usia 51 s.d 55 Tahun yaitu sejumlah 873.502 orang atau sebesar 20,98 \% kemudian disusul dengan kelompok umur 56 s.d. 60 Tahun sejumlah 724.632 orang atau sebesar 17,40 \%. Terdapat perbedaan yang cukup jauh antara jumlah ASN berumur di atas 46 tahun dan di bawah 46 tahun sehingga dalam beberapa waktu ke depan akan terdapat kesenjangan jumlah ASN dimana banyak yang sudah mencapai usia batas usia pensiun (BUP) namun generasi berikutnya tidak mencukupi baik secara jumlah maupun tingkat kematangan. 
Sementara itu jumlah ASN di Kabupaten Kulon Progo dari tahun 2014 sampai dengan 2019 juga selalu mengalami penurunan karena jumlah pegawai yang mencapai batas usia pensiun dan melakukan mutasi keluar jauh lebih banyak daripada jumlah pegawai yang diterima melalui jalur penerimaan CPNS maupun mutasi masuk ke daerah. Secara lebih jelas perkembangan jumlah ASN di Kabupaten Kulon Progo ditunjukkan oleh grafik di bawah ini :

Grafik 2

Perkembangan PNS di Kulon Progo

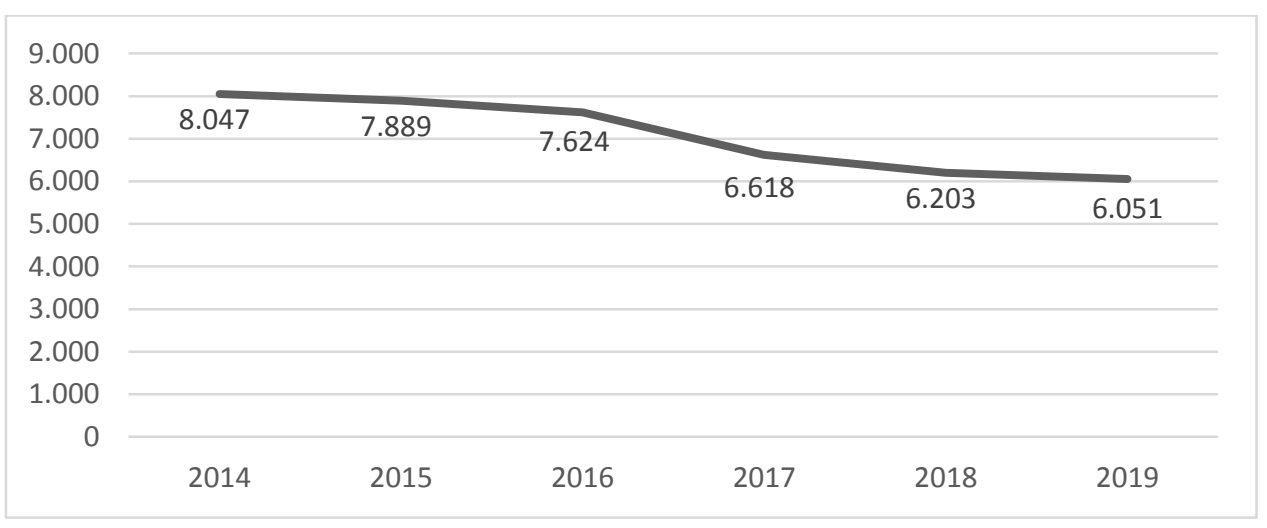

Sumber : BKPP Kulon Progo, 2020

Berdasarkan perbandingan data jumlah ASN di masing masing daerah yang dapat diperoleh di Badan Kepegawaian Pendidikan dan Pelatihan (BKPP) di masing masing wilayah, Pemerintah Kabupaten Kulon Progo memiliki ASN yang terendah dibandingkan dengan kabupaten lain di wilayah DIY yaitu Kabupaten Gunung Kidul yang memiliki ASN sebanyak 8.900 orang, Kabupaten Bantul sebanyak 8.018 orang dan Kabupaten Sleman sebanyak 8.642 orang. Untuk kebutuhan ASN di Kabupaten Kulon Progo sejumlah 9.041 orang ASN dengan rincian sebanyak 5.766 merupakan ASN Jabatan Fungsional Tertentu yaitu ASN yang melaksanakan ketugasan berdasarkan keahlian dan ketrampilan tertentu serta bersifat mandiri sebagai contohnya adalah guru, dokter, apoteker, bidan, perawat, penyuluh, auditor dan pustakawan. Sedangkan untuk kebutuhan ASN jabatan fungsional umum atau yang sekarang disebut dengan pelaksana sejumlah 2.634 orang dan jabatan structural sebanyak 641 orang. Tabel di bawah ini menggambarkan kebutuhan ASN di Kabupaten Kulon Progo dengan kondisi riil yang ada di masing masing instansi. 
138 | Kurniawan, Suswanta Manajemen Aparatur Sipil...

Tabel 2

Persebaran ASN Per Instansi

\begin{tabular}{|c|c|c|c|c|c|c|c|}
\hline \multirow{2}{*}{ No } & \multirow{2}{*}{ Instansi } & \multicolumn{3}{|c|}{ JFU / Pelaksana } & \multicolumn{3}{|c|}{ JFT } \\
\hline & & Formasi & Riil & Selisih & Formasi & Riil & Selisih \\
\hline 1 & BKPP & 43 & 23 & -20 & 13 & 7 & -6 \\
\hline 2 & BKAD & 111 & 46 & -65 & 11 & 0 & -11 \\
\hline 3 & BPBD & 32 & 14 & -18 & & & 0 \\
\hline 4 & Bappeda & 52 & 17 & -35 & 27 & 4 & -23 \\
\hline 5 & $\begin{array}{l}\text { Badan Kesatuan } \\
\text { Bangsa dan Politik }\end{array}$ & 18 & 8 & -10 & & & 0 \\
\hline 6 & $\begin{array}{l}\text { Dinas Pekerjaan } \\
\text { Umum PKP }\end{array}$ & 141 & 78 & -63 & 13 & 10 & -3 \\
\hline 7 & $\begin{array}{l}\text { Dinas Perpustakaan } \\
\text { dan Kearsipan }\end{array}$ & 22 & 11 & -11 & 30 & 18 & -12 \\
\hline 8 & $\begin{array}{l}\text { Dinas Pendidikan } \\
\text { Pemuda dan Olahraga }\end{array}$ & 384 & 225 & -159 & 3.338 & 3.150 & -188 \\
\hline 9 & $\begin{array}{l}\text { Dinas Tenaga Kerja } \\
\text { dan Transmigrasi }\end{array}$ & 40 & 17 & -23 & 45 & 14 & -31 \\
\hline 10 & $\begin{array}{l}\text { Dinas Kelautan dan } \\
\text { Perikanan }\end{array}$ & 49 & 28 & -21 & 1 & 0 & -1 \\
\hline 11 & $\begin{array}{l}\text { Dinas Komunikasi dan } \\
\text { Informatika }\end{array}$ & 33 & 9 & -24 & 29 & 9 & -20 \\
\hline 12 & $\begin{array}{l}\text { Satuan Polisi Pamong } \\
\text { Praja }\end{array}$ & 40 & 13 & -27 & 71 & 27 & -44 \\
\hline 13 & $\begin{array}{l}\text { Dinas Pertanahan dan } \\
\text { Tata Ruang }\end{array}$ & 36 & 14 & -22 & 1 & 0 & -1 \\
\hline 14 & $\begin{array}{l}\text { Dinas Lingkungan } \\
\text { Hidup }\end{array}$ & 23 & 10 & -13 & 5 & 1 & -4 \\
\hline 15 & Dinas Perhubungan & 61 & 28 & -33 & 8 & 4 & -4 \\
\hline 16 & Dinas Kebudayaan & 31 & 18 & -13 & 4 & 0 & -4 \\
\hline 17 & $\begin{array}{l}\text { Dinas Kependudukan } \\
\text { dan Pencatatan Sipil }\end{array}$ & 67 & 32 & -35 & 2 & 1 & -1 \\
\hline 18 & $\begin{array}{l}\text { Dinas PMD Dalduk \& } \\
\text { KB }\end{array}$ & 46 & 17 & -29 & 6 & 2 & -4 \\
\hline 19 & Dinas PMPT & 40 & 14 & -26 & 1 & 0 & -1 \\
\hline 20 & Dinas Kesehatan & 373 & 180 & -193 & 876 & 541 & -335 \\
\hline 21 & $\begin{array}{l}\text { Dinas Pertanian dan } \\
\text { Pangan }\end{array}$ & 120 & 46 & -74 & 176 & 64 & -112 \\
\hline 22 & $\begin{array}{l}\text { Dinas Perdagangan } \\
\text { dan Perindustrian }\end{array}$ & 99 & 40 & -59 & 13 & 6 & -7 \\
\hline 23 & Dinas Sosial PPPA & 41 & 15 & -26 & 5 & 2 & -3 \\
\hline 24 & Dinas Koperasi UMKM & 31 & 9 & -22 & 1 & 0 & -1 \\
\hline 25 & Dinas Pariwisata & 34 & 18 & -16 & 1 & 0 & -1 \\
\hline
\end{tabular}




\begin{tabular}{|c|l|c|c|c|c|c|c|}
26 & Inspektorat Daerah & 25 & 11 & -14 & 66 & 31 & -35 \\
\hline 27 & Kapanewon Wates & 27 & 17 & -10 & & & 0 \\
\hline 28 & $\begin{array}{l}\text { Kapanewon } \\
\text { Kalibawang }\end{array}$ & 21 & 13 & -8 & & & 0 \\
\hline 29 & Kapanewon Lendah & 21 & 12 & -9 & & & 0 \\
\hline 30 & $\begin{array}{l}\text { Kapanewon } \\
\text { Nanggulan }\end{array}$ & 21 & 13 & -8 & & & 0 \\
\hline 31 & Kapanewon Panjatan & 21 & 11 & -10 & & & 0 \\
\hline 32 & Kapanewon Sentolo & 21 & 13 & -8 & & & 0 \\
\hline 33 & Kapanewon Kokap & 21 & 12 & -9 & & & 0 \\
\hline 34 & Kapanewon & 21 & 12 & -9 & & & 0 \\
\hline 35 & Kamigaluh & 21 & 12 & -9 & & & 0 \\
\hline 36 & Kapanewon Galur & 21 & 11 & -10 & & & 0 \\
\hline 37 & Kapanewon Girimulyo & 21 & 11 & -10 & & & 0 \\
\hline 38 & Kapanewon Pengasih & 21 & 9 & -12 & & & 0 \\
\hline 39 & $\begin{array}{l}\text { RSUD Nyi Ageng } \\
\text { Serang }\end{array}$ & 31 & 18 & -13 & 235 & 61 & -174 \\
\hline 40 & RSUD Wates & 169 & 83 & -86 & 757 & 235 & -522 \\
\hline 41 & Sekretariat Daerah & 153 & 82 & -71 & 27 & 8 & -19 \\
\hline 42 & Sekretariat DPRD & 31 & 18 & -13 & 4 & 0 & -4 \\
\hline & & 2.634 & 1.288 & -1.346 & 5.766 & 4.195 & -1.571 \\
\hline
\end{tabular}

Sumber : BKPP Kulon Progo, 2020

Secara keseluruhan formasi ASN di Kabupaten Kulon Progo telah terisi sebanyak 5.483 atau sejumlah $67,73 \%$. Kondisi tersebut jelas bukan merupakan kondisi ideal bagi pemerintah Kabupaten Kulon Progo untuk dapat melaksanakan pemerintahan dan memberikan pelayanan publik secara optimal, menarik untuk diteliti bagaimana kebijakan kebijakan yang dilakukan oleh pemerintah daerah untuk mengatasi permasalahan tersebut.

Berdasarkan penjelasan di atas, maka lingkup manajemen ASN menjadi sangat luas sehingga penulis akan membatasi fokus penelitian terhadap kebijakan penataan ASN lingkungan Pemerintah Kabupaten Kulon Progo yang dirumuskan sebagai permasalahan penelitian sebagai berikut :

1. Bagaimanakah upaya penataan pegawai yang dilakukan oleh Pemerintah Kabupaten Kulon Progo dalam mengatasi permasalahan kekurangan pegawai yang terjadi di wilayahnya ?

2. Bagaimanakah dampak upaya tersebut terhadap efektifitas kinerja Pemerintah Kabupaten Kulon Progo? 



\section{Tinjauan Pustaka}

\section{A. Tata Kelola Pemerintahan}

Konsep governance atau lebih dikenal dengan tata kelola pemerintahan pertama kali diperkenalkan oleh Bank Dunia pada tahun 1989. Konsep tersebut tidak hanya melibatkan birokrasi dan institusi formal tetapi juga pihak swasta dan masyarakat dalam tata kelola pemerintahan. (Prasojo \& Kurniawan, 2008) Dalam perkembangan selanjutnya konsep governance tersebut berubah menjadi good governance yang mempengaruhi penyelenggaraan pemerintahan di Indonesia yang ditandai dengan diterbitkannya UU No. 25 Tahun 2009 tentang Pelayanan Publik. Good governance merupakan salah satu tujuan yang ingin dicapai dalam pelaksanaan reformasi birokrasi di Indonesia. Good governance memiliki beberapa ciri ciri diantaranya :

1. Kompetensi Kompetensi dan profesionalisme merupakan sebuah hal penting dalam penyelenggaraan pemerintahan. Penerapan akan prinsip prinsip tersebut akan meminimalisir atau menghilangkan adanya kolusi dan nepotisme.

2. Transparansi

Proses penyusunan dan pelaksanaan kebijakan ataupun penyelenggaraan pemerintahan hendaknya dilaksanakan secara terbuka, tidak diskriminatif dan memberikan kemudahan akses bagi publik.

3. Akuntabilitas

Semua tugas dan tanggung jawab yang dibebankan harus dapat diselenggarakan dengan menggunakan sumber daya secara efektif dan efisien, serta mempertanggungjawabkan setiap keputusan atau tindakan yang diambil kepada publik.

4. Partisipasi

Pemerintah berupaya untuk mendorong partisipasi aktif dari masyarakat dan pihak swasta dalam penyelenggaraan pemerintahan ataupun pelayanan publik.

5. Penegakan Hukum

Penyelenggaraan pemerintahan harus berdasarkan hukum dan peraturan perundang undangan yang jelas sehingga menjamin adanya kepastian hukum

6. Keadilan Sosial

Pemerintah mampu memberikan jaminan terhadap penerapan prinsip kesetaraan dan keadilan bagi setiap anggota masyarakat.

Salah satu indikator yang digunakan adalah terciptanya pelayanan prima kepada masyarakat yang didukung oleh penyelenggara Negara yang profesional dan bebas dari KKN. (Sunarno, 2020) Good governance merupakan sebuah sistem yang memungkinkan 
terjadinya penyelenggaraan pemerintahan yang efektif dan efisien dengan membuat sinergi antara pemerintah, swasta dan masyarakat. Apabila pihak pihak tersebut mampu bersinergi maka setiap permasalahan publik yang muncul akan dapat diatasi dengan baik. Terkait dengan hal tersebut, pemerintah memiliki peranan penting dalam mendukung tercapainya good governance yaitu :

1. Pemerintah melaksanakan peran sebagai koordinator bukan sebagai mobilisator sehingga mengurangi dominasi peran pemerintah dan meningkatkan partisipasi sektor swasta dan masyarakat.

2. Pemerintah harus melakukan penyesuaian struktur dan budaya organisasi agar memiliki kesiapan untuk menjalin kemitraan dengan swasta dan masyarakat dalam memberikan pelayanan publik.

3. Pemerintah memberikan kesempatan seluas luasnya dan melibatkan masyarakat dan pihak swasta dalam proses perencanaan, pelaksanaan serta evaluasi penyelenggaraan pelayanan publik.

4. Pemerintah harus melakukan inovasi dan lebih adaptif terhadap pemenuhan kebutuhan dan penyelesaian masalah publik

\section{B. Manajemen Aparatur Sipil Negara}

Pengembangan sumber daya manusia merupakan hal yang sangat penting bagi sebuah Negara yang ingin melakukan reformasi ataupun perbaikan di dalam sektor publik. (Setiyono, 2014) Kinerja dan kemampuan instansi pemerintah sangat ditentukan dengan kemampuan aparaturnya. Sehingga ada pendapat yang menyatakan bahwa kualitas SDM berpengaruh positif terhadap kinerja organisasi. (Rosiadi et al., 2018) Hal tersebut juga diperkuat dengan kondisi bahwa jika seorang individu tidak ditempatkan dalam tempat yang benar dalam waktu yang tepat maka performa pemerintah akan terlihat buruk. (Coggburn, 2005)

Terkait dengan hal tersebut, ada beberapa peranan terkait dengan manajemen aparatur sipil negara yaitu :

1. Menetapkan jumlah, kualitas dan penempataan kerja sesuai dengan kebutuhan.

2. Menetapkan pola rekruitmen, seleksi dan penempatan berdasarkan asas right man in right place dan right man in the right job

3. Menetapkan program kesejahteraan, pengembangan, promosi dan pensiun

4. Memprediksi kebutuhan SDM di masa mendatang

5. Melaksanakan pendidikan dan penilaian kinerja

6. Mengatur penataan dan mutasi SDM 
Peranan tersebut yang kemudian dilaksanakan oleh Kementerian Pendayagunaan Aparatur Negara dan Reformasi Birokrasi, Badan Kepegawaian Negara (BKN) dan Lembaga Administrasi Negara (LAN) di tingkat pusat dan Badan Kepegawaian Daerah (BKD) atau Badan Kepegawaian Pendidikan dan Pelatihan (BKPP) di lingkungan pemerintah daerah. Di Indonesia manajemen SDM di organisasi sektor publik atau lebih dikenal dengan birokrasi sudah diatur dalam UU No. 5 Tahun 2014 tentang Aparatur Sipil Negara. Manajemen dilakukan berdasarkan merit sistem yaitu kebijakan manajemen ASN yang berdasarkan kepada kualifikasi, kompetensi, dan kinerja secara adil dan wajar tanpa membedakan latar belakang suku, agama, ras, warna kulit, umur, gender, status perkawinan, agama, dan kondisi kecacatan.

\section{Analisis Jabatan}

Analisis jabatan merupakan sebuah kegiatan dalam rangka pengumpulan informasi yang berhubungan dengan jabatan secara sistematis dan teratur (Wirawan, 2015) Informasi tersebut diantaranya terkait dengan fungsi, dimensi dan indikator pekerjaan, pendidikan dan kompetensi yang diperlukan, teknologi yang dibutuhkan dan prosedur pelaksanaan pekerjaan, kompensasi hasil pekerjaan serta teknis penilaian kinerja. Hasil dari analisis jabatan menjadi pedoman dalam proses manajemen SDM meliputi rekruitmen dan penempatan, penyusunan program latihan dan pengembangan, perbaikan struktur dan komposisi SDM di organisasi/perusahaan, penambahan fasilitas dan perlengkapan yang dibutuhkan (Sedarmayanti, 2010). Dalam melakukan analisis jabatan ada beberapa hal yang harus diperhatikan diantaranya :

1. Uraian Pekerjaan

Uraian pekerjaan meliputi seluruh informasi yang memuat tentang tugas dan tanggung jawab, kondisi pekerjaan, hubungan pekerjaan, dan aspek aspek pekerjaan pada jabatan tertentu. Uraian pekerjaan ini harus disampaikan kepada seluruh personil yang ada sehingga dapat memahami tugas yang harus dilakukan serta tanggung jawab yang diberikan.

2. Spesifikasi Pekerjaan

Spesifikasi pekerjaan merupakan kriteria yang diperlukan oleh seseorang yang akan melaksanakan pekerjaan. Hal tersebut terdiri dari latar belakang Pendidikan, ketrampilan dan kepribadian yang dipersyaratkan.

3. Evaluasi Jenis Pekerjaan

Evaluasi jenis pekerjaan adalah melakukan penilaian terhadap tingkat kesulitan dan resiko dalam pelaksanaan pekerjaan serta kompensasi yang diberikan. Pekerjaan dengan resiko dan tingkat kesulitan tinggi seharusnya 
mendapatkan kompensasi yang lebih besar dibandingkan jenis pekerjaan dengan resiko dan tingkat kesulitan yang rendah.

D. Sistem Akuntabilitas Kinerja Instansi Pemerintah

Salah satu agenda penting di dalam reformasi birokrasi adalah perbaikan sistem manajemen pemerintahan. Manajemen pemerintahan diharapkan mampu untuk meningkatkan akuntabilitas serta peningkatan kinerja yang berorientasi kepada hasil. Pemerintah telah menetapkan penerapan sistem pertanggungjawaban yang disebut dengan sistem akuntabilitas kinerja instansi pemerintahan (SAKIP). SAKIP merupakan rangkaian sistematik dari berbagai aktivitas, alat dan prosedur yang dirancang untuk tujuan penetapan dan pengukuran, pengumpulan data, pengklarifikasian, pengikhtisaran, dan pelaporan kinerja dalam rangka pertanggungjawaban dan peningkatan kinerja instansi pemerintah. Dasar hukum dari pelaksanaan SAKIP adalah Peraturan Presiden Nomor 29 Tahun 2014 Tentang Sistem Akuntabilitas Kinerja Instansi Pemerintah. Tujuan dari penerapan SAKIP adalah mendorong terciptanya akuntabilitas kinerja instansi pemerintah sebagai salah satu prasyarat untuk terciptanya pemerintahan yang baik dan terpercaya atau Good Governance. Sementara sasaran yang ingin dicapai dalam pelaksanaan SAKIP terwujudnya transparansi instansi pemerintah, terwujudnya partisipasi masyarakat dalam pelaksanaan pembangunan nasional, dan menjadikan instansi pemerintah yang akuntabel, yang dapat beroperasi secara efektif dan efisien serta responsive terhadap aspirasi masyarakat. Hasil akhir yang ingin dicapai adalah terpeliharanya kepercayaan masyarakat kepada pemerintah. Ruang lingkup yang dinilai dalam evaluasi SAKIP adalah perencanaan kinerja (bobot 30 $\%$ ), pengukuran kinerja (bobot $25 \%$ ), pelaporan kinerja (bobot $15 \%$ ), evaluasi internal (bobot $10 \%$ ) dan Capaian Kinerja (bobot $20 \%$ ). Penilaian menggunakan skala nilai antara 1 s.d. 100 dengan Predikat AA akan diberikan kepada instansi yang memperoleh nilai antara 90 - 100, A dengan nilai 80 - 90, BB dengan nilai 70 - 80, B dengan nilai 60 - 70, CC dengan nilai 50 - 60, C dengan nilai $30-50$, dan $D$ untuk yang memiliki nilai di bawah 30 .

\section{Metode Penelitian}

Metode penelitian yang digunakan adalah deskriptif-kualitatif. Pemilihan metode tersebut bertujuan agar memperoleh gambaran yang utuh dan realistis terkait dengan proses penataan dan pengembangan kompetensi SDM ASN di lingkungan pemerintah Kabupaten Kulon Progo Daerah Istimewa Yogyakarta. Teknik pengumpulan data yang dilakukan adalah dengan melakukan wawancara, dokumentasi dan observasi. Wawancara dilakukan terhadap personil dan pejabat yang berasal dari Badan 
Kepegawaian Pendidikan dan Pelatihan (BKPP) Kabupaten Kulon Progo sebagai instansi teknis yang memiliki tugas pokok dan fungsi terkait dengan pengelolaan ASN. Analisis data yang digunakan adalah dengan menguraikan dan menafsirkan data yang diperoleh dengan menggunakan interactive model analysis. (Miles \& Huberman, 1994) Kegiatan analisis terbagi menjadi tiga kegiatan yaitu reduksi data, penyajian data dan penarikan kesimpulan.

\section{Pembahasan}

Berdasarkan perhitungan kategori jumlah pegawai yang berpedoman kepada Peraturan Kepala Badan Kepegawaian Negara Nomor 37 Tahun 2011 Tentang Pedoman Penataan Pegawai Negeri Sipil, Pemerintah Kabupaten Kulon Progo termasuk ke dalam Instansi dengan kategori Kurang. Hal ini dikarenakan jumlah ASN yang ada masih lebih kecil dari angka toleransi sebesar 2,5 \%. Idealnya jumlah ASN di Pemerintah Kabupaten Kulon Progo adalah sesuai dengan formasi yaitu sejumlah 9.041 orang namun BKN memberikan toleransi sebesar 2,5\% atau sebesar 226 orang. Jika jumlah pegawai yang dimiliki masih dalam kisaran angka toleransi tersebut yaitu berkisar antara 8.815 s.d 9.267 orang maka termasuk dalam kategori sesuai, jika melebihi angka toleransi tersebut yaitu melebihi 9.267 orang masuk ke dalam kategori lebih dan jika kurang dari angka toleransi tersebut yaitu kurang dari 8.815 orang termasuk ke dalam kategori kurang.

Untuk mengatasi permasalahan tersebut maka dilakukan langkah langkah penataan ASN yang bertujuan untuk memperoleh kuantitas, kualitas, komposisi ASN yang tepat sehingga dapat mengoptimalkan kinerja institusi. sebagai berikut :

Langkah yang pertama adalah melakukan analis jabatan sehingga diperoleh informasi terkait dengan uraian jabatan, syarat jabatan, peta jabatan sehingga dapat diketahui komposisi dan kekuatan pegawai di masing masing instansi. Hal tersebut sudah dilaksanakan dan hasilnya tercantum dalam Peraturan Bupati Kulon Progo Nomor 94 Tahun 2016 Tentang Kualifikasi Jabatan Fungsional Tertentu Pada Pemerintah Daerah yang telah diubah terakhir dengan Peraturan Bupati Kulon Progo Nomor 44 Tahun 2018 dan Peraturan Bupati Kulon Progo Nomor 22 Tahun 2019 Tentang Kualifikasi Jabatan Pimpinan Tinggi dan Jabatan Administrasi Pada Pemerintah Daerah yang telah diubah dengan Peraturan Bupati Kulon Progo Nomor 96 Tahun 2019. Dalam Peraturan Bupati tersebut dijelaskan secara rinci mengenai sebutan jabatan, jenis eselon, ikhtisar jabatan yang menjelaskan deskripsi tugas dari setiap jabatan, serta persyaratan untuk menduduki jabatan meliputi pendidikan, golongan ruang, dan diklat.

Langkah ke dua adalah berdasarkan hasil analisa jabatan yang sudah dilakukan, BKPP melakukan pemetaan pada masing masing instansi untuk mengetahui kekuatan pegawai selanjutnya dilakukan redistribusi pegawai antar instansi di lingkungan 
Pemerintah Kabupaten Kulon Progo, selain itu karena kesenjangan antara formasi jabatan dan kondisi riil pegawai masih tinggi kemudian juga dilakukan melakukan penarikan ASN yang diperbantukan kepada instansi lain sesuai dengan syarat jabatan. Penarikan ini di lakukan terhadap penjaga sekolah maupun petugas kebersihan di berbagai sekolah serta sekdes pada pemerintah desa yang memenuhi persyaratan untuk dialih tugaskan dalam jabatan pelaksana.

Langkah ke tiga adalah menyusun perencanaan dalam jangka waktu 5 tahun ke depan dan melakukan penerimaan pegawai dengan pendekatan positive growth yaitu melakukan penerimaan pegawai dengan jumlah yang lebih besar dibandingkan dengan jumlah pegawai yang memasuki batas usia pensiun. Hal tersebut masih belum dapat terlaksana sepenuhnya dan terhenti di dalam proses penyusunan perencanaan dikarenakan dalam setiap penerimaan pegawai baru, harus mendapatkan persetujuan dari kementerian Pendayagunaan Aparatur Negara dan Reformasi Birokrasi. Setiap tahun Pemerintah Kabupaten Kulon Progo telah mengajukan formasi CPNS, namun tidak semua formasi yang diusulkan mendapatkan persetujuan dari Kementerian Pendayagunaan Aparatur Negara dan Reformasi Birokrasi. Kebijakan dari pemerintah, walaupun usulan kebutuhan ASN sudah berdasarkan kepada peta jabatan namun tetap menggunakan prinsip zero growth dengan memperhatikan jumlah ASN yang akan memasuki batas usia pensiun. Kondisi tersebut juga ditambah dengan tidak semua formasi jabatan dapat terisi sesuai dengan formasi khususnya jabatan yang memerlukan kualifikasi dan ketrampilan khusus seperti formasi jabatan untuk disabilitas, dokter spesialis, dokter ahli, dan guru bagi penyandang disabilitas karena jumlah yang melamar tidak memenuhi kuota atau tidak ada peserta yang memenuhi syarat passing grade kelulusan.

Langkah ke empat adalah melakukan pengangkatan tenaga honorer non PNS atau tenaga kontrak. Untuk memenuhi kebutuhan pegawai di lingkungan Pemerintah Kabupaten Kulon Progo maka disusunlah Peraturan Bupati Kulon Progo Nomor 70 Tahun 2017 Tentang Pengelolaan Tenaga Kontrak Pada Pemerintah Daerah sebagai landasan hukum dalam pengangkatan tenaga kontrak. Adanya pengangkatan tenaga kontrak tersebut mampu menjadi solusi untuk pemenuhan kebutuhan pegawai yang mendesak dikarenakan proses pengangkatan dapat berjalan lebih mudah dan tidak seperti proses seleksi PNS. Namun sejak ditetapkannya Peraturan Pemerintah Nomor 49 tahun 2018 Tentang Manajemen Pegawai Pemerintah Dengan Perjanjian Kerja yang salah satunya adalah larangan bagi pemerintah daerah untuk mengangkat pegawai honorer, maka sudah tidak dimungkinkan lagi untuk mengangkat pegawai honorer non ASN. Di sisi lain masih belum jelasnya regulasi dari pemerintah pusat terkait dengan pengangkatan 
pegawai pemerintah dengan perjanjian kerja juga mempersulit pemerintah daerah untuk memenuhi kebutuhan pegawai sehingga satu satunya peluang penambahan pegawai adalah dengan seleksi CPNS.

Dalam keterbatasan jumlah pegawai Pemerintah Kabupaten Kulon Progo tetap berusaha agar kinerja pemerintahan dapat berjalan secara efektif. Kriteria yang digunakan mengukur kinerja pemerintahan adalah Penilaian Sistem Akuntabilitas Kinerja Instansi Pemerintah (SAKIP). Berdasarkan penilaian terhadap SAKIP Pemerintah kabupaten Kulon Progo oleh Kementerian Pendayagunaan Aparatur Negara dan Reformasi Birokrasi terdapat peningkatan nilai yang cukup signifikan dari nilai $\mathrm{C}$ pada tahun 2013 kemudian meningkat menjadi B pada tahun 2014 dan 2015, mendapatkan nilai BB pada tahun 2017 dan 2018 dan terakhir pada tahun 2019 mendapatkan nilai A.

\section{Kesimpulan dan Saran}

Manajemen pegawai yang sudah dilakukan oleh Pemerintah Kabupaten Kulon Progo sudah dilaksanakan sesuai dengan kebutuhan riil dan hasil analisa jabatan walaupun dalam beberapa tahapan masih belum berjalan dengan maksimal. Masih ditemukan syarat jabatan yang belum terpenuhi sehingga masih terdapat kesenjangan jabatan. Proses penempatan pegawai yang belum sesuai dengan kualifikasi dan kompetensi dikarenakan menyesuaikan dengan komposisi pegawai yang sudah ada.

Di tengah keterbatasan tersebut Pemerintah Kabupaten Kulon Progo mampu untuk membuktikan bahwa kinerja pemerintahan dapat berjalan dengan optimal. Hal itu dapat dilihat dari penilaian Standar Akuntabilitas Kinerja Instansi Pemerintah (SAKIP) yang selalu mengalami peningkatan dari tahun 2013, terakhir pada penilaian SAKIP tahun 2019 Pemerintah Kabupaten Kulon Progo mendapatkan predikat A. Hasil tersebut membuktikan bahwa Pemerintah Kabupaten Kulon Progo memiliki komitmen yang kuat dalam menggunakan anggaran secara efektif dan efisien dalam pelaksanaan pembangunan sehingga terwujud tata kelola pemerintahan yang baik.

\section{DAFTAR PUSTAKA}

\section{Buku-buku}

Agus, A. (2019). Patologi Birokrasi Dan Agenda Strategi: Kolaborasi Pendekatan New Public Management Dan New Public Service Melalui Model Citizens Charter. Politea: Jurnal Politik Islam, 2(1), 77-90.

Coggburn, J. D. (2005). The Benefits Of Human Resource Centralization: Insights From A Survey Of Human Resource Directors In A Decentralized State. Public Administration Review, 65(4), 424-435.

Miles, M. B., \& Huberman, A. M. (1994). Qualitative Data Analysis: An Expanded Sourcebook. Sage. 
Sedarmayanti. (2010). Sumber Daya Manusia Dan Produktivitas Kerja. Mandar Maju.

Setiyono, B. (2014). Pemerintahan Dan Manajemen Sektor Publik. Caps.

Wirawan. (2015). Evaluasi Kinerja Sumber Daya Manusia: Teori, Aplikasi Dan Penelitian. Salemba Empat.

\section{Jurnal}

Agus, A. (2019). Patologi Birokrasi Dan Agenda Strategi: Kolaborasi Pendekatan New Public Management Dan New Public Service Melalui Model Citizens Charter. Politea: Jurnal Politik Islam, 2(1), 77-90.

Coggburn, J. D. (2005). The Benefits Of Human Resource Centralization: Insights From A Survey Of Human Resource Directors In A Decentralized State. Public Administration Review, 65(4), 424-435.

Djajakusumah, R. D. R. (2016). Pengaruh Restrukturisasi Organisasi Dan Penggunaan Teknologi Informasi Terhadap Efektivitas Organisasi Dinas Daerah Di Kota Bekasi Effect Of Restructuring The Organization And Use Of Information Technology On The Effectiveness Of Organization Regional Office In The City Bekasi [Phd Thesis]. Unpas.

Idris, A. (2017). Bingkai Reformasi Birokrasi Indonesia. Jurnal Paradigma (Jp), 2(3), 352-357.

Prasojo, E., \& Kurniawan, T. (2008). Reformasi Birokrasi Dan Good Governance: Kasus Best Practices Dari Sejumlah Daerah Di Indonesia. The 5 Th International Symposium Of Jurnal Antropologi Indonesia, 1-15.

Rosiadi, A., Setiawan, M., \& Moko, W. (2018). Praktek Manajemen Sumber Daya Manusia Berbasis Kompetensi Pada Organisasi Sektor Publik. Jurnal Manajemen Dan Kewirausahaan, 6(2), 156.

Sunarno, S. (2020). Reformasi Birokrasi Dalam Rangka Mewujudkangood Governance Di Indonesia. Jurnal Wacana Kinerja: Kajian Praktis-Akademis Kinerja Dan Administrasi Pelayanan Publik, 10(2), 7-16.

\section{Peraturan Perundang-Undangan}

Undang Undang Nomor 25 Tahun 2009 Tentang Pelayanan Publik

Undang Undang Nomor 5 Tahun 2014 Tentang Aparatur Sipil Negara

Peraturan Pemerintah Nomor 49 Tahun 2018 Tentang Manajemen Pegawai Pemerintah Dengan Perjanjian Kerja

Peraturan Presiden Nomor 81 Tahun 2010 Tentang Grand Desain Reformasi Birokrasi $2010-2024$

Peraturan Presiden Nomor 29 Tahun 2014 Tentang Sistem Akuntabilitas Kinerja Instansi Pemerintah.

Peraturan Kepala Badan Kepegawaian Negara Nomor 37 Tahun 2011 Tentang Pedoman Penataan Pegawai Negeri Sipil

Peraturan Bupati Kulon Progo Nomor 94 Tahun 2016 Tentang Kualifikasi Jabatan Fungsional Tertentu Pada Pemerintah Daerah

Peraturan Bupati Kulon Progo Nomor 70 Tahun 2017 Tentang Pengelolaan Tenaga Kontrak Pada Pemerintah Daerah 
148 | Kurniawan, Suswanta Manajemen Aparatur Sipil...

Peraturan Bupati Kulon Progo Nomor 44 Tahun 2018 Tentang Perubahan Kedua Atas Peraturan Bupati Nomor 94 Tahun 2016 Tentang Kualifikasi Jabatan Fungsional Tertentu Pada Pemerintah Daerah

Peraturan Bupati Kulon Progo Nomor 22 Tahun 2019 Tentang Kualifikasi Jabatan Pimpinan Tinggi Dan Jabatan Administrasi Pada Pemerintah Daerah

Peraturan Bupati Kulon Progo Nomor 96 Tahun 2019 Tentang Perubahan Atas Peraturan Bupati Kulon Progo Nomor 22 Tahun 2019 Tentang Kualifikasi Jabatan Pimpinan Tinggi Dan Jabatan Administrasi Pada Pemerintah Daerah 